\title{
Uromedic ${ }^{\circledR}$ Pumpkin Seed Derived $\Delta 7$-Sterols, Extract and Oil Inhibit $5 \alpha$-Reductases and Bind to Androgen Receptor in Vitro
}

\author{
Stefan Heim¹, Stephanie Seibt' ${ }^{2}$, Heike Stier ${ }^{2}$, Margret I Moré ${ }^{2 *}$ \\ ${ }^{1}$ Omega Pharma Manufacturing GmbH \& Co. KG, Benzstr. 25, Herrenberg, Germany \\ ${ }^{2}$ analyze \& realize $\mathrm{GmbH}$, Department of Consulting and Strategic Innovation, Waldseeweg 6, Berlin, Germany \\ Email: *mmore@analyze-realize.com
}

How to cite this paper: Heim, S., Seibt, S., Stier, H. and Moré, M.I (2018) Uromedic ${ }^{\circ}$ Pumpkin Seed Derived $\Delta 7$-Sterols, Extract and Oil Inhibit $5 \alpha$-Reductases and Bind to Androgen Receptor in Vitro. Pharmacology \& Pharmacy, 9, 193-207. https://doi.org/10.4236/pp.2018.96015

Received: May 21, 2018

Accepted: June 26, 2018

Published: June 29, 2018

Copyright (C) 2018 by authors and Scientific Research Publishing Inc. This work is licensed under the Creative Commons Attribution International License (CC BY 4.0).

http://creativecommons.org/licenses/by/4.0/

\section{(c) (i) Open Access}

\begin{abstract}
Dihydrotestosterone (DHT) is implicated in the development of benign prostate hyperplasia (BPH). We investigated if Uromedic ${ }^{\oplus}$ pumpkin (variety of Cucurbita pepo L. convar. citrullinina GREB. var. styriaca GREB) seed soft extract (active ingredients of GRANUFINK ${ }^{\oplus}$ Prosta forte $500 \mathrm{mg}$ ), seed oil and isolated $\Delta 7$-sterols could inhibit the conversion of $\left[1,2,6,7-{ }^{3} \mathrm{H}(\mathrm{N})\right]$-testosterone to DHT by $5 \alpha$-reductases. Also, we tested competition with $\left[{ }^{3} \mathrm{H}\right]$-DHT for binding to the androgen receptor (AR). Pumpkin seed oil and pumpkin seed soft extract were identified as moderately active inhibitors of $5 \alpha-\mathrm{R} 1$ and $5 \alpha$-R2, with almost similar inhibitory capacities $\left(\mathrm{IC}_{50}<5 \mathrm{mg} / \mathrm{ml}\right.$ for $5 \alpha$-R1 and about $\mathrm{IC}_{50}=6 \mathrm{mg} / \mathrm{ml}$ for $\left.5 \alpha-\mathrm{R} 2\right)$. The isolated $\Delta 7$-sterols were more active inhibitors $\left(\mathrm{IC}_{50}=0.3 \mathrm{mg} / \mathrm{ml}\right.$ for $5 \alpha-\mathrm{R} 1, \mathrm{IC}_{50}=1.0 \mathrm{mg} / \mathrm{ml}$ for $5 \alpha$-R2). All three test compounds bound to the AR dose-dependently, with strong binding by $\Delta 7$-sterols $\left(\mathrm{IC}_{50}=0.2 \mathrm{mg} / \mathrm{ml}\right)$ and weaker binding by pumpkin seed oil $\left(\mathrm{IC}_{50}=0.4 \mathrm{mg} / \mathrm{ml}\right)$ and pumpkin seed soft extract $\left(\mathrm{IC}_{50}=1.1 \mathrm{mg} / \mathrm{ml}\right)$. We propose that inhibition of $5 \alpha$-reductases and competitive binding to the AR are mechanisms of action, by which the Uromedic ${ }^{\oplus}$ pumpkin seed derived test compounds, most specifically $\Delta 7$-sterols, counteract DHT and thereby exert clinically positive effects on the prostate, as well as bladder-strengthening effects.
\end{abstract}

\section{Keywords}

5-Alpha-Reductases $5 \alpha$-R1 and $5 \alpha$-R2, Androgen Receptor,

Dihydrotestosterone, Uromedic ${ }^{\circledast}$ Pumpkin Seed Oil and Soft Extract,

(Delta-7) $\Delta 7$-Sterols 


\section{Introduction}

Benign prostate hyperplasia (BPH) is commonly found in men, with a worldwide prevalence of from $20 \%-62 \%$ in men over 50 years [1]. Affected men suffer from the frequent urge to urinate, especially at night, weakened urinary flow, delayed start of urination, intermittency, urine leaking, incomplete bladder emptying as well as difficult or painful urination. The steroidal androgen dihydrotestosterone (DHT) has been implicated in the development and maintenance of $\mathrm{BPH}$.

A common BPH treatment option is the inhibition of the 5-alpha-reductases, enzymes catalyzing DHT formation from testosterone [2] [3]. There are three 5 -alpha-reductase isoenzymes: $5 \alpha$ - $\mathrm{R} 1$ is expressed in low levels in the prostate, whereas $5 \alpha$-R2 is highly expressed there. $5 \alpha$ - $\mathrm{R} 3$ appears to have a role in malignant tissues [3] [4].

5-alpha-reductase-inhibition has previously been shown for saw palmetto (Serenoa repens (Bartr.) Small.) extracts (and for several contained fatty acids) [5] [6], as well as for Urtica dioica Linn. extract [7]. 5-alpha-reductase-inhibition was also proposed for Cucurbita pepo L. (pumpkin) seed preparations [8] .

A further possibility to reduce the pathologic effects of DHT represents the inhibitory competition with DHT for its binding site at the androgen receptor (AR). The AR is activated by binding either testosterone or the more potent androgen dihydrotestosterone. Upon binding, AR undergoes conformational changes and translocates from the cytoplasm to the nucleus, where it dimerizes and regulates transcription by binding to androgen response elements [9]. The AR has two isoforms, AR-A and AR-B [10].

Pumpkin (Cucurbita pepo L.) seeds or preparations thereof have long been recognized for their potential of relieving lower urinary tract symptoms related to benign prostatic hyperplasia or to an overactive bladder [11]. The seed soft extract of a special pumpkin breed ("Uromedic ${ }^{\oplus}$ pumpkin", a variety of Cucurbita pepo L. convar. citrullinina GREB. var. styriaca GREB) [12] [13] is rich in $\Delta 7$-sterols, which are typical components in pumpkin seeds [14] and seeds of other Cucurbitaceae, as well as in Amaranthaceae [15]. $\Delta 7$-sterols were shown to influence the prostate metabolism [16] [17]. Furthermore, they competitively reduced the binding of DHT to human fibroblasts [18].

Extracts from C. pepo, Prunus Africana (Hook. f.) Kalkman and S. repens displayed antiandrogenic activity in an AR responsive reporter gene assay [19]. However, the molecular effectors appear to vary: in the case of $P$. africana, N-butylbenzenesulfonamide was characterized as active constituent [19], whereas in $S$. repens, certain fatty acids may act by binding-instead-to the alpha-1-adrenergic, muscarinic and 1,4-dihydropyridine receptors, as well as to 5-alpha-reductases [6]. Interestingly, pumpkin seed oil contains high amounts of putatively active fatty acids, i.e. oleic acid and linoleic acid [12] [13].

The inhibition of the $5 \alpha$-reductases as well as the inhibitory binding to the AR 
are two possible mechanisms by which the pumpkin seed derived test compounds-Uromedic ${ }^{\circledast}$ pumpkin seed soft extract, seed oil and isolated $\Delta 7$-sterols-could exert their positive effects on the prostate and bladder system, especially in relation to BPH. Thus, we tested inhibition of $5 \alpha$-reductase and competitive androgen receptor-binding using radioactively labeled ligands.

\section{Materials and Methods}

Experimental procedures were performed by “rent-a-lab Dr. Carsten Tober" in Reutlingen, Germany, between April-September 2016.

\subsection{Test Compounds and Materials}

Test compounds: 1. Pumpkin seed oil of Uromedic ${ }^{\oplus}$ pumpkin seeds (Material 3000000293, Omega Pharma batch: 511062, vendor/batch: 603827/283484), one of the active substances in "GRANUFINK ${ }^{\circledast}$ Prosta" (Omega Pharma Deutschland $\mathrm{GmbH}$ ). 2. $\Delta 7$-sterols isolated from Uromedic ${ }^{\circledast}$ pumpkin seed oil; 3. Pumpkin seed soft extract (DER 15-25:1) from Uromedic ${ }^{\circledast}$ pumpkin seeds; extraction solvent ethanol 92\% (m/m) (Material 3000000299, Omega Pharma batch: 531057, vendor/batch: 600516/15000533); active substance of GRANUFINK ${ }^{\circledast}$ Prosta forte $500 \mathrm{mg}$ (Omega Pharma Deutschland $\mathrm{GmbH}$ ), supplying approximately $30 \mathrm{mg} /$ day $\Delta 7$-sterols [14] (Supplementary Table S1).

The test compounds were dissolved and stored in DMSO (dimethyl sulfoxide) at $4^{\circ} \mathrm{C}$.

Commercial hexane extracted saw palmetto fruit extract (Serenoa repens W. Bartram; DER 7-11:1) served as positive control (5 $\alpha$-reductase-inhibition). Finasteride $\left(\mathrm{C}_{23} \mathrm{H}_{36} \mathrm{~N}_{2} \mathrm{O}_{2}, 5 \alpha\right.$-reductase-inhibitor) was used to quantify $5 \alpha$-reductase inhibition, and DHT to quantify AR binding.

AR (recombinant rat protein, ligand binding domain, code: A15675) was from ThermoFisher Scientific (Braunschweig, Germany). Dihydrotestosterone (DHT) (code: A83809), testosterone (code: T1500) and finasteride (code: F1293) were from Sigma (Taufkirchen, Germany). [ $\left.{ }^{3} \mathrm{H}\right]$-Dihydrotestosterone ([ $\left.{ }^{3} \mathrm{H}\right]-\mathrm{DHT}$, code: NET 453), [1,2,6,7- $\left.{ }^{3} \mathrm{H}(\mathrm{N})\right]$-testosterone, code: NET370) and Ysi Copper His-Tag SPA Beads (code: RPNQ0096) were from PerkinElmer (Rodgau, Germany). Other chemicals were from Sigma or VWR.

\subsection{Preparation of Sources of $5 \alpha-\mathrm{R} 1$ and $5 \alpha-\mathrm{R} 2$}

Sprague Dawley rats (Elevage Janvier, Le Genest, Saint Isle, France) were sacrificed by decapitation. Liver was dissected on ice, frozen in liquid nitrogen and stored at $-80^{\circ} \mathrm{C}$. For the experiments at $\mathrm{pH} 7.0(5 \alpha$-R1), rat liver microsomes were prepared as described [20]. For the experiments at pH 5.0 (5a-R2), a crude rat liver enzyme preparation was used as described [21].

\section{3. $5 \alpha$-Reductase Activity Assays}

The enzyme reactions were mainly carried out as described [21]. In a total volume 
of $90 \mu \mathrm{l}$ radioactive $\left({ }^{3} \mathrm{H}\right.$-testosterone; $\left.0.5 \mu \mathrm{Ci}\right)$ and non-radioactive $(9.5 \mu \mathrm{M})$ testosterone, $0.5 \mathrm{mM}$ beta-NADPH and liver microsomes/crude liver enzyme preparation were incubated in assay buffer ( $0.1 \mathrm{M}$ Tris-citrate, $\mathrm{pH} 5.0$ or 7.0) in a shaking water bath at $37^{\circ} \mathrm{C}$ for 20 or $60 \mathrm{~min}$. The assay was terminated by the addition of $10 \mu \mathrm{l} 2.8 \mathrm{M} \mathrm{NaOH}$. Educt $\left({ }^{3} \mathrm{H}\right.$-testosterone) and products $\left({ }^{3} \mathrm{H}-\mathrm{DHT}\right.$, ${ }^{3} \mathrm{H}$-alpha-adiol and other metabolites) were separated by HPLC from each other using an adapted [22] and validated method, and using a Beckman System Gold HPLC (Beckman Instruments, San Ramon, CA, USA) fitted with an Onyx monolitic C18 (Phenomenex Ltd. Deutschland, Aschaffenburg, Germany) reversed phase column $(100 \times 3 \mathrm{~mm})$. Chromatography was performed isocratically for $15 \mathrm{~min}$ at a flow rate of $0.5 \mathrm{ml} / \mathrm{min}$ with $0.2 \% \mathrm{NH}_{4} \mathrm{OH}$ in $65 \%$ methanol as mobile phase, separating ${ }^{3} \mathrm{H}$-testosterone and ${ }^{3} \mathrm{H}$-DHT. Radioactivity in collected fractions was determined in a scintillation counter (WinSpektral, Wallac, Finland). Data typically represent results gained by two experiments performed in duplicate (see results section).

Data evaluation: The inhibition by $10 \mu \mathrm{M}$ finasteride $(3.7254 \mu \mathrm{g} / \mathrm{ml})$ was considered $100 \%$ inhibition, the inhibitory activity of the vehicle/solvent $0 \%$ inhibition. The inhibition of the test compounds was calculated relative to that of finasteride. $\mathrm{IC}_{50}$ values were determined by non-linear regression (algorithm "sigmoidal dose-response"; GraphPadPrism, San Diego, USA).

\subsection{Competitive AR Binding Assay}

The competition of each test compound (or DHT) with $\left[{ }^{3} \mathrm{H}\right]-\mathrm{DHT}$ for binding to the rat recombinant AR was measured by detecting $\left[{ }^{3} \mathrm{H}\right]-\mathrm{DHT}$. The basic assay conditions were taken from Freyberger and Ahr [23] and adapted to the scintillation proximity assay (SPA) format, in which beads emit light when a radio-labeled molecule is in proximity. Incubation was in assay buffer $(50 \mathrm{mM}$ Tris- $\mathrm{HCl} \mathrm{pH} 7.5,800 \mathrm{mM} \mathrm{NaCl}, 10 \mathrm{mg} / \mathrm{ml}$ human $\gamma$-globulin, $0.05 \%$ bovine serum albumine) at room temperature for $90 \mathrm{~min}$. Then Ysi Copper His-Tag SPA beads were added and the incubation continued for another $60 \mathrm{~min}$. The radioactivity-induced light was determined by a microplate reader (Microbeta, Wallac, Finland). For each test compound, two measurement series were done, each in duplicate.

Data evaluation: In order to exclude binding to non-specific sites, incubations using the radioactive ligand $\left[{ }^{3} \mathrm{H}\right]-\mathrm{DHT}$ and unlabeled DHT as the natural ligand of the AR were run simultaneously at different concentrations. Excess unlabeled DHT occupied the high-affinity specific sites and blocked the binding of $\left[{ }^{3} \mathrm{H}\right]$-DHT to the AR. As a result, the radio-labeled ligand only bound to the non-specific sites. Such radioactive binding in the presence of excess unlabeled DHT was considered non-specific binding.

The amount of $\left[{ }^{3} \mathrm{H}\right]$-DHT bound in the absence of unlabeled DHT was referred to as total binding. Specific binding was calculated as:

Total (radioactive) binding - Non-specific (radioactive) binding $=$ Specific binding 
Thus, the data of the reference compound DHT are presented as total bound radioactivity (in counts per minute, $\mathrm{cpm}$ ). Test compound data are presented as specific radioligand binding to the receptor. The specific inhibition in $\%$ was calculated as (\% specific radioligand binding mean -100$) \times(-1) . \mathrm{IC}_{50}$ values were determined by non-linear regression (algorithm "sigmoidal dose-response"; Graph Pad Prism, San Diego, USA).

\section{Results}

\subsection{Rat Liver $5 \alpha$-Reductase Activity-Assay Validation}

Rat liver microsomes were shown to obtain higher levels of 5-alpha-reductase compared to rat prostate microsomes [20]. Therefore, rat liver microsomes were used as source of $5 \alpha$-R1. For $5 \alpha$-R2, a crude liver preparation was found to be more active. $5 \alpha$-R1 exhibits a broad $\mathrm{pH}$ optimum (between $\mathrm{pH} 6.0$ - 8.5), whereas $5 \alpha$ - 22 shows a narrow acidic $\mathrm{pH}$ optimum (pH 5 - 5.5) [4]. To distinguish $5 \alpha-\mathrm{R} 1$ from $5 \alpha-\mathrm{R} 2$, the assays for $5 \alpha$-R1 were performed at $\mathrm{pH} 7.0$, and those for $5 \alpha-\mathrm{R} 2$ at $\mathrm{pH} 5.0$ [21]. Experiments at $\mathrm{pH} 5.0$ led to a very low, almost negligible signal from the rat liver microsomal preparation (source of $5 \alpha$-R1; data not shown).

At $\mathrm{pH} 7.0$ the reference compound finasteride inhibited the activity of $5 \alpha$-R1 derived from rat liver microsomes with an $\mathrm{IC}_{50}$ of $48 \mathrm{nM}$ (Figure 1). This compares to a published $\mathrm{IC}_{50}$ of $21 \mathrm{nM}$ [20], demonstrating test system suitability. A commercial hexanic extract of Serenoa repens [5] was able to inhibit $5 \alpha$-R1 with an $\mathrm{IC}_{50}=4.9 \mathrm{mg} / \mathrm{ml}$ and $5 \alpha-\mathrm{R} 2$ with an $\mathrm{IC}_{50}=1.8 \mathrm{mg} / \mathrm{ml}$.

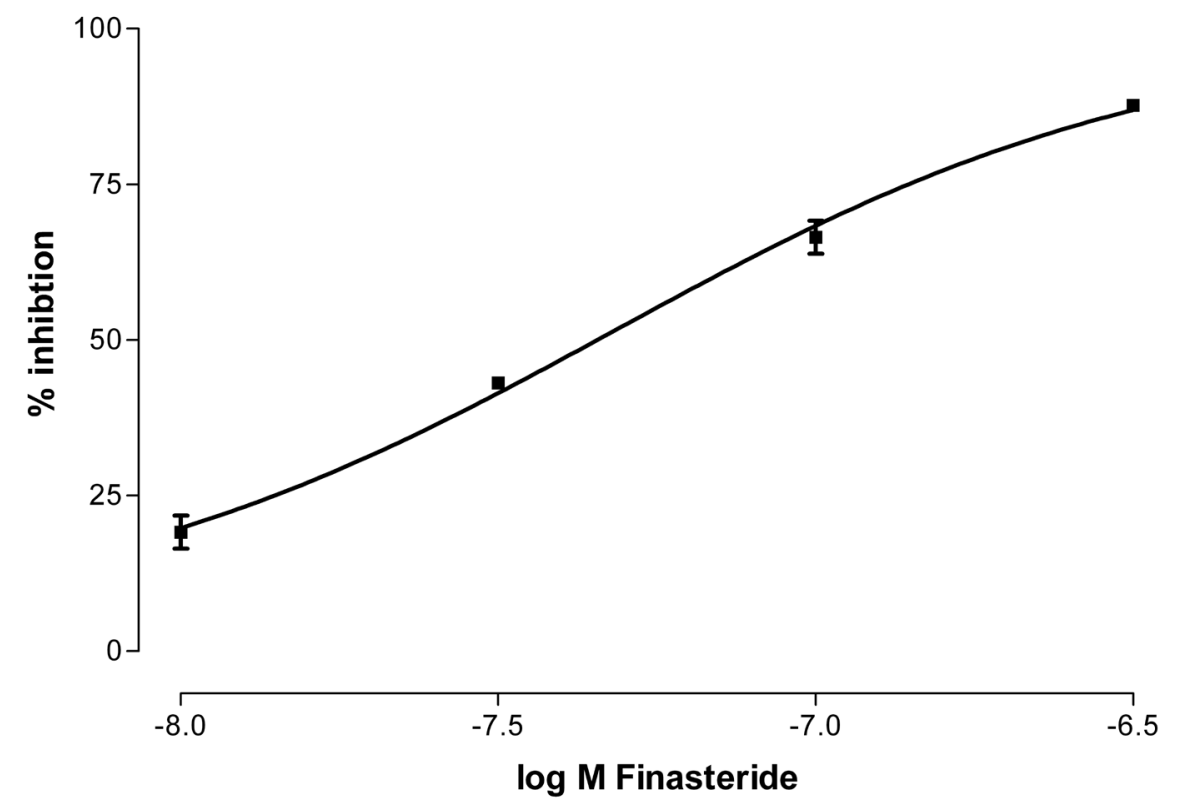

Figure 1. Inhibition of 5-alpha-reductase isoform I, derived from rat liver microsomes, at pH 7.0 by finasteride. Data represent the mean inhibition of enzyme activity (\%) of one

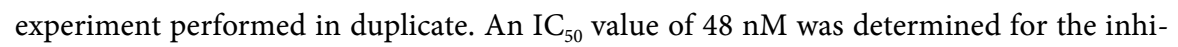
bition by finasteride. 


\subsection{Inhibitory Effect of the Test Compounds on Microsomal Rat Liver $5 \alpha-\mathrm{R} 1$}

The inhibitory potential of the test compounds on $5 \alpha$-R1 was tested using our validated assay at $\mathrm{pH} 7$, favoring $5 \alpha$-R1 activity. Table 1 shows that pumpkin seed oil $(5 \mathrm{mg} / \mathrm{ml})$, pumpkin seed soft extract $(5 \mathrm{mg} / \mathrm{ml})$ and $\Delta 7$-sterols $(0.5 \mathrm{mg} / \mathrm{ml})$ had similar inhibitory capacities, between $70 \%-95 \%$ compared to $10 \mu \mathrm{M}$ finasteride. The results for $\Delta 7$-sterols showed a dose dependency. The calculated $\mathrm{IC}_{50}$ values are indicated.

\subsection{Inhibitory Effect of the Test Compounds on Rat Liver $5 \alpha$-R2}

The inhibitory potential of the test compounds on $5 \alpha$-R2 was tested using our validated assay at $\mathrm{pH} 5$, favouring $5 \alpha$-R2 activity. Table 2 shows that pumpkin seed oil ( $5 \mathrm{mg} / \mathrm{ml})$, pumpkin seed soft extract $(5 \mathrm{mg} / \mathrm{ml})$ and $\Delta 7$-sterols $(0.5 \mathrm{mg} / \mathrm{ml})$ had similar inhibitory capacities, between $25 \%-50 \%$ compared to $10 \mu \mathrm{M}$ finasteride. The results for $\Delta 7$-sterols showed a dose dependency. The calculated $\mathrm{IC}_{50}$ values are indicated.

Table 1. Inhibition of microsomal rat liver $5 \alpha-\mathrm{R} 1$ by the Uromedic ${ }^{\star}$ pumpkin-derived test compounds at $\mathrm{pH} 7.0$.

\begin{tabular}{|c|c|c|c|c|c|}
\hline \multirow{2}{*}{ Compound } & \multirow{2}{*}{ Concentration } & \multicolumn{2}{|c|}{$\begin{array}{l}\text { \% Inhibition }{ }^{\mathrm{a}} \\
\text { in experiments }\end{array}$} & \multirow{2}{*}{$\begin{array}{l}\% \text { Inhibition }^{\mathrm{a}} \\
\text { (mean) }\end{array}$} & \multirow{2}{*}{$\mathrm{IC}_{50}{ }^{\mathrm{c}}$} \\
\hline & & 1 & 2 & & \\
\hline Pumpkin seed oil & $5 \mathrm{mg} / \mathrm{ml}$ & 95.3 & 72.2 & 83.75 & $<5 \mathrm{mg} / \mathrm{ml}$ \\
\hline \multirow[t]{2}{*}{ Pumpkin seed soft extract } & $5 \mathrm{mg} / \mathrm{ml}$ & 91.8 & 71.0 & 81.4 & $<5 \mathrm{mg} / \mathrm{ml}$ \\
\hline & $0.5 \mathrm{mg} / \mathrm{ml}$ & 79.7 & 69.5 & 74.6 & \\
\hline \multirow[t]{2}{*}{$\Delta 7$-sterols } & & & & & $0.3 \mathrm{mg} / \mathrm{ml}$ \\
\hline & $0.1 \mathrm{mg} / \mathrm{ml}$ & not done & 42.6 & 42.6 & \\
\hline
\end{tabular}

a-c: see Table 2.

Table 2. Inhibition of rat liver $5 \alpha-\mathrm{R} 2$ by the Uromedic ${ }^{\oplus}$ pumpkin-derived test compounds at $\mathrm{pH}$ 5.0.

\begin{tabular}{|c|c|c|c|c|c|}
\hline \multirow{2}{*}{ Compound } & \multirow{2}{*}{ Concentration } & \multicolumn{2}{|c|}{$\begin{array}{l}\text { \% Inhibition }{ }^{\mathrm{a}} \text { in } \\
\text { experiments }^{\mathrm{b}}\end{array}$} & \multirow{2}{*}{$\begin{array}{c}\% \text { Inhibition }^{\mathrm{a}} \\
\text { (mean) }\end{array}$} & \multirow{2}{*}{$\mathrm{IC}_{50}{ }^{\mathrm{c}}$} \\
\hline & & 1 & 2 & & \\
\hline Pumpkin seed oil & $5 \mathrm{mg} / \mathrm{ml}$ & 38.2 & 47.5 & 42.85 & $5.8 \mathrm{mg} / \mathrm{ml}$ \\
\hline Pumpkin seed soft extract & $5 \mathrm{mg} / \mathrm{ml}$ & 36.4 & 50.1 & 43.25 & $5.8 \mathrm{mg} / \mathrm{ml}$ \\
\hline \multirow{2}{*}{$\Delta 7$-sterols } & $0.5 \mathrm{mg} / \mathrm{ml}$ & 26.8 & $0.8^{\mathrm{d}}$ & 26.8 & \multirow{2}{*}{$1.0 \mathrm{mg} / \mathrm{m}$} \\
\hline & $0.1 \mathrm{mg} / \mathrm{ml}$ & not done & 4.9 & 4.9 & \\
\hline
\end{tabular}

a: Inhibition relative to $10 \mu \mathrm{M}(3.7254 \mu \mathrm{g} / \mathrm{ml})$ finasteride (100\% inhibition); activity with vehicle DMSO was considered $0 \%$ inhibition. b: Both experiments in duplicate; means of duplicate measurements shown; c: $\mathrm{IC}_{50}$ values: concentration of test compound causing $50 \%$ inhibition. $\mathrm{d}$ : This value was judged as outlier and not taken into consideration. 


\subsection{AR Binding-Assay Validation}

DHT is the natural ligand of the AR. DHT competed with $\left[{ }^{3} \mathrm{H}\right]-\mathrm{DHT}$ for binding to the AR with an $\mathrm{IC}_{50}$ of $8.5 \mathrm{nM}$ (Figure 2). This is in agreement with an $\mathrm{IC}_{50}$ of $4.2 \mathrm{nM}$ described in literature [23], demonstrating test system suitability.

\subsection{Binding of the Test Compounds to ARs}

Overlaid mean specific binding data of pumpkin seed soft extract, pumpkin seed oil and $\Delta 7$-sterols are depicted graphically (Figure 3(a) and Figure 3(b)); numeric data is shown in Supplementary Tables S2-S4. All test compounds show typical concentration dependent binding. Strongest specific AR binding was observed for $\Delta 7$-sterols (mean $\mathrm{IC}_{50}=0.2 \mathrm{mg} / \mathrm{ml}$, corresponding to $0.48 \mathrm{mmol} / \mathrm{l}$ ) and weaker binding for pumpkin seed oil (mean $\mathrm{IC}_{50}=0.4 \mathrm{mg} / \mathrm{ml}$ ) and pumpkin seed soft extract (mean $\left.\mathrm{IC}_{50}=1.1 \mathrm{mg} / \mathrm{ml}\right)$ (Table 3$)$.

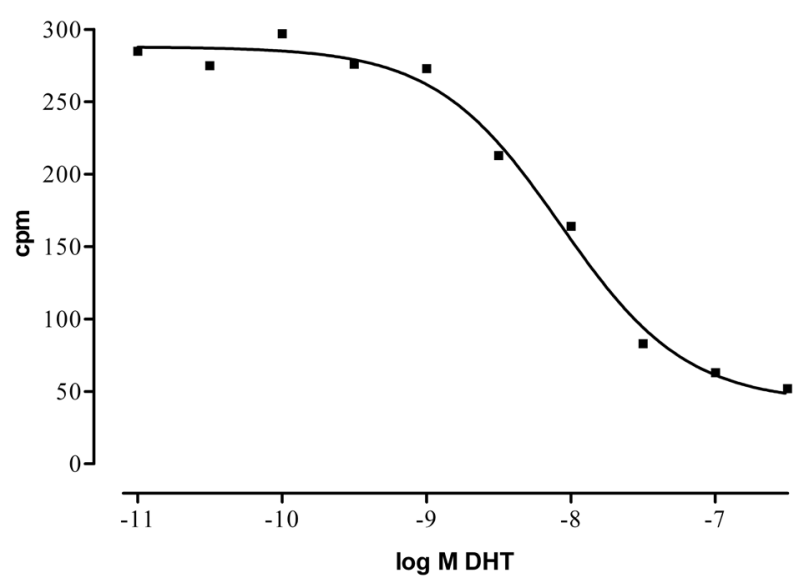

Figure 2. Concentration-dependent competition of DHT with $\left[{ }^{3} \mathrm{H}\right]-\mathrm{DHT}$ for binding to rat recombinant $\mathrm{AR}$. An $\mathrm{IC}_{50}$ value of $8.5 \mathrm{nM}$ was determined for the binding of DHT. Data represents the bound radioactivity (cpm).

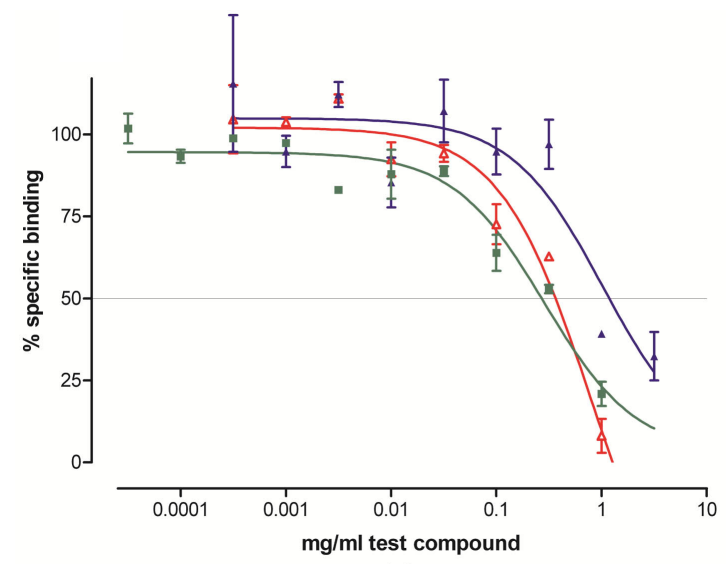

(a)

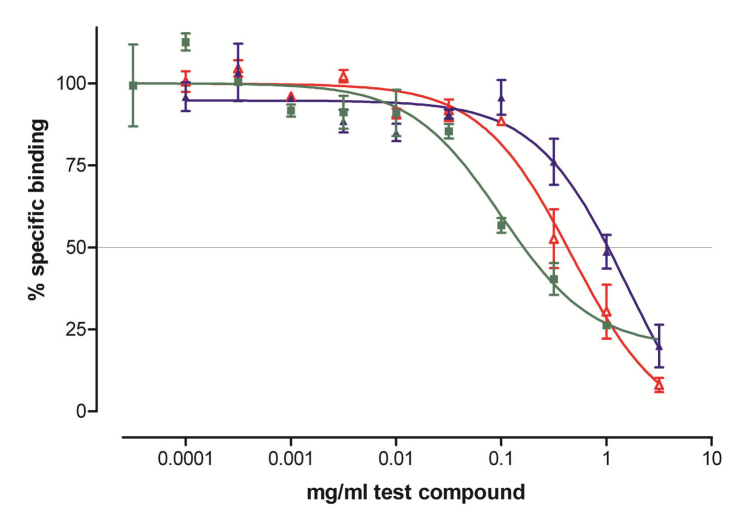

(b)

Figure 3. Competitive binding of the test compounds at the AR. The test compounds pumpkin seed soft extract ( $\boldsymbol{\Delta}$, blue) and pumpkin seed oil $\left(\triangle\right.$, red) and $\Delta 7$-sterols ( $\boldsymbol{\square}$, green) competed with $\left[{ }^{3} \mathrm{H}\right]$-DHT for binding to the rat AR within two independent measurements ( $\mathrm{a}$ and $\mathrm{b}$ ). Data in each graph represent the mean specific binding \pm standard error of the mean (SEM) of duplicate measurements. Calculated $\mathrm{IC}_{50}$-values from each experiment are indicated in Table 3. See Supplementary Tables $\mathrm{S} 2$-S4 for numeric data. 
Table 3. $\mathrm{IC}_{50}$ values obtained within the competitive AR binding assay.

\begin{tabular}{ccccc}
\hline \multirow{2}{*}{ Compound } & \multicolumn{3}{c}{$\mathrm{IC}_{50}$ in $\mathrm{mg} / \mathrm{ml}$} & \multirow{2}{*}{$\mathrm{IC}_{50}$ in mmol/l } \\
\cline { 2 - 4 } & 1. Measurement & 2. Measurement & Mean & \\
\hline Pumpkin seed oil & 0.36 & 0.43 & 0.4 & $/$ \\
Pumpkin seed soft extract & 1.17 & 1.04 & 1.1 & $/$ \\
$\Delta 7$-sterols & 0.27 & 0.16 & 0.2 & $0.48^{\mathrm{a}}$ \\
\hline
\end{tabular}

a: Calculated using the molecular mass of the main $\Delta 7$-sterol within pumpkin seeds: $\Delta^{7.25}$-stigmastadienol $412 \mathrm{~g} / \mathrm{mol}[14]$.

\section{Discussion}

\subsection{Inhibition of Human 5-Alpha-Reductases}

As previously published, rat liver tissue expresses 5-alpha-reductases. Microsomal liver preparations were used as source for $5 \alpha$-R1 (isoform I). However, the same was found unsuitable for measurement of isoform II at $\mathrm{pH}$ 5.0, which was instead investigated in crude liver preparations. Assay validation was done for both preparations using known enzyme inhibitors. Both pumpkin seed soft extract and oil showed similar inhibitory capacities (both: $\mathrm{IC}_{50}<5 \mathrm{mg} / \mathrm{ml}$ for $5 \alpha$-R1 and $\mathrm{IC}_{50} \approx 6 \mathrm{mg} / \mathrm{ml}$ for $5 \alpha$-R2). The isolated $\Delta 7$-sterols $\left(\mathrm{IC}_{50}=0.3 \mathrm{mg} / \mathrm{ml}\right.$ for $5 \alpha-\mathrm{R} 1, \mathrm{IC}_{50}=1.0$ for $5 \alpha-\mathrm{R} 2$ ) were more potent than the pumpkin seed soft extract or oil, most likely since the $\Delta 7$-sterols are the main active principle within pumpkin seeds regarding anti-androgenic activity.

\subsection{Androgen Receptor Binding}

The test compounds inhibited the $\left[{ }^{3} \mathrm{H}\right]$-DHT binding to AR in a concentration-dependent manner (Table 3), with $\mathrm{IC}_{50}(\Delta 7$-sterols $\left.)=0.2 \mathrm{mg} / \mathrm{ml}\right), \mathrm{IC}_{50}$ (pumpkin seed oil) $=0.4 \mathrm{mg} / \mathrm{ml}$ and $\mathrm{IC}_{50}$ (pumpkin seed soft extract) $=1.1 \mathrm{mg} / \mathrm{ml}$. This dose-dependency indicates the capacity of all three test compounds to bind to the AR.

Among the tested substances, the $\Delta 7$-sterols had the lowest $\mathrm{IC}_{50}$ and thus bind most potently to the AR.

Chang and Liao classified the antagonistic effects of different cyclic hydrocarbons on the AR [24]. Accordingly, the binding of $\Delta 7$-sterols (mean $\mathrm{IC}_{50}$ of $0.48 \mathrm{mmol} / \mathrm{l}$ ) corresponds to moderately active substances $\left(\mathrm{IC}_{50}\right.$ range $\left.0.1-2 \mathrm{mmol} / \mathrm{l}\right)$. In a published experiment, human cells were pre-incubated with $\Delta 7$-sterols and then treated with DHT. In a concentration-dependent manner, a reduced binding of DHT to its binding sites could be demonstrated [18]. This goes along with our findings.

\subsection{Extrapolation to the in Vivo Situation}

The inhibition of 5-alpha-reductase by $\Delta 7$-sterols and their inhibitory binding to $\mathrm{AR}$ are plausible due to the similar structure of these compounds compared to DHT [18] [25]. Several studies support that our in vitro observations also take effect in vivo: 
Trevisan et al. 2012 found that orally administered $\Delta 7$ sterol (alpha-spinasterol) was well absorbed by mice [26]. Pumpkin seed or pumpkin seed oil in the diet of BPH animal models inhibited prostate growth [13] [27] [28] [29]. Effects were observed with only $40 \mathrm{mg}$ pumpkin seed oil/kg body weight [28]. Furthermore, patients taking $90 \mathrm{mg}$ of a $\Delta 7$ sterol mixture isolated from Uromedic ${ }^{\oplus}$ pumpkin seeds 3 - 4 days before prostatectomy had a lower DHT content in the operated prostate tissue than control patients [17]. Thus anti-androgen effects seen in our studies presumably take effect also in vivo, while, the safety of pumpkin seed soft extract and pumpkin seed oil has been established by human data [11] [30] [31] [32]. As a next step, the isolated $\Delta 7$ sterols (versus seed soft extract and seed oil) could be tested in BPH animal models, and finally in BPH patients.

\subsection{Study Limitations}

In order to get more reliable $\mathrm{IC}_{50}$ values, more experiments using at least 3 different concentrations of the test compounds (especially in the case of the 5-alpha-reductases), and using more independent measurements should be done. Since all our experiments were done using rat enzymes, potential differences in binding and inhibition to human orthologues cannot be excluded.

\section{Conclusion}

In our study, Uromedic ${ }^{\circledast}$ pumpkin seed soft extract (active ingredients of GRANUFINK $^{\oplus}$ Prosta forte $500 \mathrm{mg}$ ), pumpkin seed oil and-more effectively-isolated $\Delta 7$-sterols inhibit $5 \alpha$-reductase and competitively bind to the AR in vitro. It is plausible that the $\Delta 7$-sterols are the active compounds contained within the pumpkin seed soft extract and oil, regarding these activities. This is supported by the dose-dependency of the observed inhibitory effects, as well as by the lower $\mathrm{IC}_{50}$ values of the $\Delta 7$-sterols compared to the seed soft extract or oil. Other constituents, such as fatty acids, may also be involved. Our results are promising for a mechanistic understanding of pumpkin seed-derived preparations, and more specifically $\Delta 7$-sterols, regarding anti-androgenic effects and the inhibition of $5 \alpha$-reductase.

\section{Acknowledgements and Funding}

We thank Dr. S. Förster for her valuable contribution on planning the studies. Stefan Heim is employee of Omega Pharma Manufacturing GmbH \& Co. KG, who funded the study. Stephanie Seibt, Dr. Heike Stier and Margret Moré, Ph.D. are employees of the consulting company analyze \& realize $\mathrm{GmbH}$.

\section{References}

[1] Yeboah, E.D. (2016) Prevalence of Benign Prostatic Hyperplasia and Prostate Cancer in Africans and Africans in the Diaspora. Journal of the West African College of Surgeons, 6, 1-30.

[2] Nicholson, T.M. and Ricke, W.A. (2011) Androgens and Estrogens in Benign Prostatic Hyperplasia: Past, Present and Future. Differentiation, 82, 184-199. 
https://doi.org/10.1016/j.diff.2011.04.006

[3] Wang, K., Fan, D.D., Jin, S., Xing, N.Z. and Niu, Y.N. (2014) Differential Expression of 5-alpha-reductase Isozymes in the Prostate and Its Clinical Implications. Asian Journal of Andrology, 16, 274-279. https://doi.org/10.4103/1008-682X.123664

[4] Azzouni, F., Godoy, A., Li, Y. and Mohler, J. (2012) The 5-alpha-reductase Isozyme Family: A Review of Basic Biology and Their Role in Human Diseases. Advances in Urology, 2012, 530121. https://doi.org/10.1155/2012/530121

[5] Raynaud, J.P., Cousse, H. and Martin, P.M. (2002) Inhibition of Type 1 and Type 2 5-alpha-reductase Activity by Free Fatty Acids, Active Ingredients of Permixon. The Journal of Steroid Biochemistry and Molecular Biology, 82, 233-239. https://doi.org/10.1016/S0960-0760(02)00187-5

[6] Abe, M., Ito, Y., Oyunzul, L., Oki-Fujino, T. and Yamada, S. (2009) Pharmacologically Relevant Receptor Binding Characteristics and 5-alpha-reductase Inhibitory Activity of Free Fatty Acids Contained in Saw Palmetto Extract. Biological and Pharmaceutical Bulletin, 32, 646-650. https://doi.org/10.1248/bpb.32.646

[7] Nahata, A. (2014) Dixit VK. Evaluation of 5-alpha-reductase Inhibitory Activity of Certain Herbs Useful as Antiandrogens. Andrologia, 46, 592-601. https://doi.org/10.1111/and.12115

[8] Dreikorn, K. and Schonhofer, P.S. (1995) Status of Phytotherapeutic Drugs in Treatment of Benign Prostatic Hyperplasia. Urologe A, 34, 119-129.

[9] Meehan, K.L. and Sadar, M.D. (2003) Androgens and Androgen Receptor in Prostate and Ovarian Malignancies. Frontiers in Bioscience, 8, d780-800. https://doi.org/10.2741/1063

[10] Wilson, C.M. and McPhaul, M.J. (1994) A and B Forms of the Androgen Receptor Are Present in Human Genital Skin Fibroblasts. Proceedings of the National Academy of Sciences of the United States of America, 91, 1234-1238. https://doi.org/10.1073/pnas.91.4.1234

[11] EMA Committee on Herbal Medicinal Products (HMPC). Community Herbal Monograph on Cucurbita pepo L., Semen EMA/HMPC/136024/2010. http://www.ema.europa.eu/docs/en_GB/document_library/Herbal_-_Community_ herbal_monograph/2013/03/WC500140761.pdf

[12] Fruhwirth, G. and Hermetter, A. (2007) Seeds and Oil of the Styrian Oil Pumpkin: Components and Biological Activities. European Journal of Lipid Science and Technology, 109, 1128-1140. https://doi.org/10.1002/ejlt.200700105

[13] Committee on Herbal Medicinal Products (HMPC). Assessment Report on Cucurbita pepo L., Semen EMA/HMPC/136022/2010 2011.

http://www.ema.europa.eu/docs/en_GB/document_library/Herbal_-_HMPC_assess ment_report/2011/10/WC500116579.pdf

[14] Muller, C. and Bracher, F. (2015) Determination by GC-IT/MS of Phytosterols in Herbal Medicinal Products for the Treatment of Lower Urinary Tract Symptoms and Food Products Marketed in Europe. Planta Medica, 81, 613-620. https://doi.org/10.1055/s-0035-1545906

[15] Munger, L.H., Jutzi, S., Lampi, A.M. and Nystrom, L. (2015) Comparison of Enzymatic Hydrolysis and Acid Hydrolysis of Sterol Glycosides from Foods Rich in Delta(7)-Sterols. Lipids, 50, 735-748. https://doi.org/10.1007/s11745-015-4002-3

[16] Bombardelli, E. and Morazzoni, P. (1997) Cucurbita pepo L. Fitoterapia, 68, 291-302.

[17] Schilcher, H., Dunzendorfer, U. and Ascali, F. (1987) Delta 7-sterole, das 
prostatotrope Wirkprinzip in Kürbissamen? Urologe Ausgabe B, 27, 316-319.

[18] Schilcher, H. and Schneider, H.-J. (1990) Beurteilung von Kürbissamen in fixer Kombination mit weiteren pflanzlichen Wirkstoffen zur Behandlung des Symptomenkomplexes bei BPH. Urologe (B), 30, 62-66.

[19] Schleich, S., Papaioannou, M., Baniahmad, A. and Matusch, R. (2006) Extracts from Pygeum africanum and Other Ethnobotanical Species with Antiandrogenic Activity. Planta Medica, 72, 807-813. https://doi.org/10.1055/s-2006-946638

[20] Iwai, A., Yoshimura, T., Wada, K., Watabe, S., Sakamoto, Y., Ito, E. and Miura, T. (2013) Spectrophotometric Method for the Assay of Steroid 5alpha-Reductase activity of Rat Liver and Prostate Microsomes. Analytical Sciences, 29, 455-459. https://doi.org/10.2116/analsci.29.455

[21] Pratis, K., O’Donnell, L., Ooi, G.T., McLachlan, R.I. and Robertson, D.M. (2000) Enzyme Assay for 5alpha-Reductase Type 2 Activity in the Presence of 5alpha-Reductase Type 1 Activity in Rat Testis. The Journal of Steroid Biochemistry and Molecular Biology, 75, 75-82. https://doi.org/10.1016/S0960-0760(00)00139-4

[22] Yang, H.Z., Miao, Z.R., He, Z.X., Ji, S. and Zeng, F.S. (1988) Separation of Testosterone and Dihydrotestosterone in Semen by High Performance Liquid Chromatography. Journal of Liquid Chromatography, 11, 3253-3259. https://doi.org/10.1080/01483918808076793

[23] Freyberger, A. and Ahr, H.J. (2004) Development and Standardization of a Simple Binding Assay for the Detection of Compounds with Affinity for the Androgen Receptor. Toxicology, 195, 113-126. https://doi.org/10.1016/j.tox.2003.09.008

[24] Wong, C., Kelce, W.R., Sar, M. and Wilson, E.M. (1995) Androgen Receptor Antagonist versus Agonist Activities of the Fungicide Vinclozolin Relative to Hydroxyflutamide. The Journal of Biological Chemistry, 270, 19998-20003. https://doi.org/10.1074/jbc.270.34.19998

[25] Chang, C. and Liao, S. (1987) Topographic Recognition of Cyclic Hydrocarbons and Related Compounds by Receptors for Androgens, Estrogens and Glucocorticoids. The Journal of Steroid Biochemistry and Molecular Biology, 27, 123-131. https://doi.org/10.1016/0022-4731(87)90303-7

[26] Trevisan, G., Rossato, M., Walker, C., Klafke, J., Rosa, F., Oliveira, S., et al. (2012) Identification of the Plant Steroid Alpha-Spinasterol as a Novel Transient Receptor Potential Vanilloid 1 Antagonist with Antinociceptive Properties. Journal of Pharmacology and Experimental Therapeutics, 343, 258-269. https://doi.org/10.1124/jpet.112.195909

[27] Abdel-Rahman, M. (2006) Effects of Pumpkin Seed (Cucurbita pepo L.) Diets on Benign Prostatic Hyperplasia (BPH): Chemical and Morphometric Evaluation in Rats. World Journal of Chemistry, 1, 33-40.

[28] Gossell-Williams, M., Davis, A. and O’Connor, N. (2006) Inhibition of Testosterone-Induced Hyperplasia of the Prostate of Sprague-Dawley Rats by Pumpkin Seed Oil. Journal of Medicinal Food, 9, 284-286.

https://doi.org/10.1089/jmf.2006.9.284

[29] Tsai, Y.S., Tong, Y.C., Cheng, J.T., Lee, C.H., Yang, F.S. and Lee, H.Y. (2006) Pumpkin Seed Oil and Phytosterol-F Can Block Testosterone/Prazosin-Induced Prostate Growth in Rats. Urologia Internationalis, 77, 269-274. https://doi.org/10.1159/000094821

[30] Bach, D. (2000) Placebokontrollierte Langzeittherapiestudie mit Kürbissamenextrakt bei BPH-bedingten Miktionsbeschwerden. Der Urologe, 40, 437-443. https://doi.org/10.1007/s001310050432 
[31] Schiebel-Schlosser, G. and Friederich, M. (1998) Kürbissamen in der Phytotherapie der BPH. Zeitschrift für Phytotherapie, 19, 17-76.

[32] Vahlensieck, W., Theurer, C., Pfitzer, E., Patz, B., Banik, N. and Engelmann, U. (2015) Effects of Pumpkin Seed in Men with Lower Urinary Tract Symptoms Due to Benign Prostatic Hyperplasia in the One-Year, Randomized, Placebo-Controlled GRANU Study. Urologia Internationalis, 94, 286-295.

https://doi.org/10.1159/000362903 


\section{Supplementary}

Table S1. Herbal preparations used for the in vitro experiments.

\begin{tabular}{|c|c|c|c|}
\hline Herbal preparation & Pumpkin seed oil & Pumpkin seed soft extract & $\Delta 7$-sterols from pumpkin seed oil \\
\hline Latin binominal name & \multicolumn{3}{|c|}{ Company-owned variety of Cucurbita pepo L. convar. citrullinina GREB. var. styriaca GREB } \\
\hline Family name & \multicolumn{3}{|c|}{ Cucurbitaceae } \\
\hline Common names & \multicolumn{3}{|c|}{ Uromedic $^{\oplus}$ pumpkin } \\
\hline Plant part & \multicolumn{3}{|c|}{ Seed } \\
\hline $\begin{array}{l}\text { Country of origin of } \\
\text { herbal raw material }\end{array}$ & \multicolumn{3}{|c|}{ Hungary } \\
\hline $\begin{array}{c}\text { Batch number of commercial } \\
\text { Herbal Substance } \\
\text { (corresponding to drug } \\
\text { substance batch below) }\end{array}$ & Material 3000000293 & Material 3000000299 & Commercially not available \\
\hline $\begin{array}{l}\text { Batch number of } \\
\text { commercial drug substance } \\
\text { (used for this study) }\end{array}$ & $\begin{array}{l}\text { Omega Pharma batch: } \\
\text { 511062, vendor/batch: } \\
603827 / 283484\end{array}$ & $\begin{array}{l}\text { Omega Pharma batch: } 531057 \text {, } \\
\text { vendor/batch: 600516/15000533 }\end{array}$ & Commercially not available \\
\hline Authorized drug substance manufacturer & $\begin{array}{l}\text { Estyria Naturprodukte } \\
\text { GmbH; St. } \\
\text { Ruprecht/Raab, Austria }\end{array}$ & $\begin{array}{l}\text { Finzelberg GmbH \& Co. KG; } \\
\text { Andernach, Germany }\end{array}$ & not applicable \\
\hline Further extraction & none & none & $\begin{array}{l}\text { Isolation of } \Delta 7 \text {-sterols at the } \\
\text { Department of Pharmacy, } \\
\text { Ludwig-Maximilians-University; } \\
\text { Munich, Germany }\end{array}$ \\
\hline Test substance used for in vitro experiments & Oil & Soft extract & Isolated $\Delta 7$-sterols \\
\hline $\begin{array}{l}\text { Type and concentration of extraction } \\
\text { solvent used; drug-extract ratio (DER) }\end{array}$ & $\begin{array}{l}\text { not applicable: pure oil } \\
\text { without additives }\end{array}$ & $\begin{array}{l}\text { Extraction solvent: } \\
\text { ethanol } 92 \%(\mathrm{~m} / \mathrm{m}) \text {, DER } 15-25: 1\end{array}$ & not applicable \\
\hline $\begin{array}{l}\text { Content of quantified } \\
\text { herbal constituents/purity }\end{array}$ & $100 \%$ oil, Ph. Eur. & $95 \%$ - 99\% native extract & $\begin{array}{l}\text { not applicable, since no extract: } \\
\text { isolated } \Delta 7 \text {-sterols }\end{array}$ \\
\hline Contained excipients & none & 1-5\% hydrophobic colloidal silica & none \\
\hline Identification & Fatty acid profile (TLC) & Phytosterols (GC) & $\Delta 7$-sterols (GC-IT-MS) \\
\hline Typical marker compounds & $\begin{array}{l}\text { Phytosterols, } \\
\text { Fatty acid profile }\end{array}$ & Phytosterols & $\begin{array}{l}\Delta 7 \text {-sterols (e.g. } \Delta^{7,25} \text {-stigmasterol, } \\
\text { spinasterol, } \Delta^{7} \text {-avenasterol) }\end{array}$ \\
\hline
\end{tabular}

GC-IT-MS, gas chromatography ion trap mass spectrometry (Muller C, Bracher F. Determination by GC-IT/MS of phytosterols in herbal medicinal products for the treatment of lower urinary tract symptoms and food products marketed in Europe. Planta Med 2015; 81: 613 - 620); TLC, thin layer chromatography; GC, gas chromatography.

Table S2. Individual data of the AR binding measurements for pumpkin seed soft extract.

\begin{tabular}{|c|c|c|c|c|c|}
\hline & \multirow{2}{*}{$\begin{array}{l}\text { Pumpkin seed soft extract in } \\
\qquad \mathrm{mg} / \mathrm{ml}\end{array}$} & \multicolumn{3}{|c|}{$\%$ Specific radioligand binding } & \multirow{2}{*}{$\begin{array}{c}\% \text { Specific inhibition } \\
\text { Mean } \pm \text { SEM }\end{array}$} \\
\hline & & 1. Value & 2. Value & Mean & \\
\hline \multirow[t]{5}{*}{ 1. Measurement } & 3.16000 & 25.0 & 39.7 & 32.4 & $67.6 \pm 7.4$ \\
\hline & 1.00000 & 39.2 & 39.2 & 39.2 & $60.8 \pm 0.0$ \\
\hline & 0.31600 & 89.5 & 104.4 & 96.9 & $3.1 \pm 7.5$ \\
\hline & 0.10000 & 101.7 & 87.7 & 94.7 & $5.3 \pm 7.0$ \\
\hline & 0.03160 & 116.7 & 97.5 & 107.1 & $-7.1 \pm 9.6$ \\
\hline
\end{tabular}




\section{Continued}

\begin{tabular}{|c|c|c|c|c|c|}
\hline & 0.01000 & 92.9 & 77.7 & 85.3 & $14.7 \pm 7.6$ \\
\hline & 0.00316 & 115.9 & 108.3 & 112.1 & $-12.1 \pm 3.8$ \\
\hline & 0.00100 & 90.0 & 99.5 & 94.7 & $5.3 \pm 4.8$ \\
\hline & 0.00032 & 94.6 & 136.3 & 115.4 & $-15.4 \pm 20.8$ \\
\hline & 0.00010 & $65.9^{*}$ & $62.0^{*}$ & I & l \\
\hline \multirow[t]{10}{*}{ 2. Measurement } & 10.00000 & 26.4 & 13.5 & 19.9 & $80.1 \pm 6.5$ \\
\hline & 3.16000 & 53.8 & 43.5 & 48.7 & $51.3 \pm 5.1$ \\
\hline & 1.00000 & 69.0 & 83.1 & 76.1 & $23.9 \pm 7.0$ \\
\hline & 0.31600 & 90.4 & 101.0 & 95.7 & $4.3 \pm 5.3$ \\
\hline & 0.10000 & 91.9 & 89.2 & 90.5 & $9.5 \pm 1.3$ \\
\hline & 0.03160 & 87.7 & 82.4 & 85.0 & $15.0 \pm 2.7$ \\
\hline & 0.01000 & 85.0 & 91.9 & 88.5 & $11.5 \pm 3.4$ \\
\hline & 0.00316 & 94.9 & 96.1 & 95.5 & $4.5 \pm 0.6$ \\
\hline & 0.00100 & 112.1 & 94.5 & 103.3 & $-3.3 \pm 8.8$ \\
\hline & 0.00032 & 100.3 & 91.5 & 95.9 & $4.1 \pm 4.4$ \\
\hline
\end{tabular}

${ }^{*}$ Data excluded from further analysis, because they obviously represent measurement artifacts with an opposite value as can be expected by the corresponding dose-response-relationship.

Table S3. Individual data of the AR binding measurements for pumpkin seed oil.

\begin{tabular}{|c|c|c|c|c|c|}
\hline & \multirow{2}{*}{$\begin{array}{l}\text { Pumpkin seed } \\
\text { oil in } \mathrm{mg} / \mathrm{ml}\end{array}$} & \multicolumn{3}{|c|}{$\%$ Specific radioligand binding } & \multirow{2}{*}{$\begin{array}{c}\% \text { Specific inhibition } \\
\text { Mean } \pm \text { SEM }\end{array}$} \\
\hline & & 1. Value & 2. Value & Mean & \\
\hline \multirow[t]{10}{*}{ 1. Measurement } & 3.16000 & $20.9^{*}$ & $14.6^{*}$ & I & I \\
\hline & 1.00000 & 2.9 & 13.3 & 8.1 & $91.9 \pm 5.2$ \\
\hline & 0.31600 & 63.9 & 61.6 & 62.7 & $37.3 \pm 1.2$ \\
\hline & 0.10000 & 78.7 & 66.4 & 72.6 & $27.4 \pm 6.1$ \\
\hline & 0.03160 & 96.7 & 91.6 & 94.2 & $5.8 \pm 2.5$ \\
\hline & 0.01000 & 97.5 & 87.2 & 92.4 & $7.6 \pm 5.2$ \\
\hline & 0.00316 & 109.6 & 112.2 & 110.9 & $-10.9 \pm 1.3$ \\
\hline & 0.00100 & 105.2 & 102.2 & 103.7 & $-3.7 \pm 1.5$ \\
\hline & 0.00032 & 114.9 & 94.2 & 104.5 & $-4.5 \pm 10.4$ \\
\hline & 0.00010 & $51.8^{*}$ & $54.8^{*}$ & I & I \\
\hline \multirow[t]{10}{*}{ 2. Measurement } & 10.00000 & 5.8 & 10.2 & 8.0 & $92.0 \pm 2.2$ \\
\hline & 3.16000 & 22.2 & 38.7 & 30.4 & $69.6 \pm 8.3$ \\
\hline & 1.00000 & 43.7 & 61.6 & 52.6 & $47.4 \pm 9.0$ \\
\hline & 0.31600 & 88.5 & 88.5 & 88.5 & $11.5 \pm 0.0$ \\
\hline & 0.10000 & 88.5 & 95.0 & 91.7 & $8.3 \pm 3.3$ \\
\hline & 0.03160 & 92.2 & 89.3 & 90.7 & $9.3 \pm 1.5$ \\
\hline & 0.01000 & 104.0 & 100.2 & 102.1 & $-2.1 \pm 1.9$ \\
\hline & 0.00316 & 95.4 & 96.6 & 96.0 & $4.0 \pm 0.6$ \\
\hline & 0.00100 & 107.0 & 102.0 & 104.5 & $-4.5 \pm 2.5$ \\
\hline & 0.00032 & 103.6 & 97.4 & 100.5 & $-0.5 \pm 3.1$ \\
\hline
\end{tabular}

${ }^{*}$ Data excluded from further analysis, because they obviously represent measurement artifacts with an opposite value as can be expected by the corresponding dose-response-relationship. 
Table S4. Individual data of the AR binding measurements for $\Delta 7$-sterols.

\begin{tabular}{|c|c|c|c|c|c|}
\hline & \multirow{2}{*}{$\Delta 7$-sterols in $\mathrm{mg} / \mathrm{ml}$} & \multicolumn{3}{|c|}{$\%$ Specific radioligand binding } & \multirow{2}{*}{$\begin{array}{c}\% \text { Specific inhibition } \\
\text { Mean } \pm \text { SEM }\end{array}$} \\
\hline & & 1. Value & 2. Value & Mean & \\
\hline \multirow[t]{10}{*}{ 1. Measurement } & 1.00000 & 17.2 & 24.6 & 20.9 & $79.1 \pm 3.7$ \\
\hline & 0.31600 & 54.1 & 51.6 & 52.9 & $47.1 \pm 1.3$ \\
\hline & 0.10000 & 69.3 & 58.3 & 63.8 & $36.2 \pm 5.5$ \\
\hline & 0.03160 & 87.3 & 90.2 & 88.7 & $11.3 \pm 1.5$ \\
\hline & 0.01000 & 95.3 & 80.3 & 87.8 & $12.2 \pm 7.5$ \\
\hline & 0.00316 & 83.7 & 82.4 & 83.0 & $17.0 \pm 0.6$ \\
\hline & 0.00100 & 97.8 & 96.8 & 97.3 & $2.7 \pm 0.5$ \\
\hline & 0.00032 & 99.7 & 97.8 & 98.8 & $1.2 \pm 1.0$ \\
\hline & 0.00010 & 91.3 & 95.3 & 93.3 & $6.7 \pm 2.0$ \\
\hline & 0.00003 & 106.3 & 97.2 & 101.7 & $-1.7 \pm 4.5$ \\
\hline \multirow[t]{10}{*}{ 2. Measurement } & 1.00000 & 26.9 & 25.4 & 26.2 & $73.8 \pm 0.7$ \\
\hline & 0.31600 & 35.5 & 45.2 & 40.3 & $59.7 \pm 4.8$ \\
\hline & 0.10000 & 58.9 & 54.5 & 56.7 & $43.3 \pm 2.2$ \\
\hline & 0.03160 & 83.1 & 87.6 & 85.4 & $14.6 \pm 2.2$ \\
\hline & 0.01000 & 98.0 & 83.9 & 91.0 & $9.0 \pm 7.1$ \\
\hline & 0.00316 & 96.2 & 86.1 & 91.1 & $8.9 \pm 5.0$ \\
\hline & 0.00100 & 93.6 & 89.8 & 91.7 & $8.3 \pm 1.9$ \\
\hline & 0.00032 & 99.5 & 101.4 & 100.4 & $-0.4 \pm 0.9$ \\
\hline & 0.00010 & 115.1 & 109.9 & 112.5 & $-12.5 \pm 2.6$ \\
\hline & 0.00003 & 86.9 & 111.8 & 99.3 & $0.7 \pm 12.5$ \\
\hline
\end{tabular}

